\title{
Soybean Rust in Argentina
}

\section{A. Ivancovich, National Institute of Agricultural Technology (INTA), Pergamino, Argentina}

Soybean is the most important crop in Argentina, accounting for approximately $7 \%$ of the gross national product. Over 12.6 million hectares of soybean were planted in the 2002-2003 growing season, producing 36.0 million metric tons of soybean. There has been a tremendous growth in soybean production since 1965 , with the greatest growth occurring in the last 10 years (Table 1). Most production (91\%) is in the central area of Argentina (Humid Pampa), with 5\% produced in the northwest and $4 \%$ in the northeast region of the country. Not only has the total area planted to soybean increased, but average production has also increased from 1,624 to 2,670 $\mathrm{kg} / \mathrm{ha}$ from 1970 to 2003.

A major constraint on soybean production in Argentina is plant disease. It is estimated that between 8 and $10 \%$ of the soybean production is lost to diseases. These losses are caused by a number of diseases. While some of them can be quite destructive (e.g., sudden death syndrome and Sclerotinia stem rot), the overall damage regionally is usually limited due to the soilborne nature of these diseases.

Recently, the soybean crop has been threatened by a disease that has the potential for severe, widespread damage that could seriously limit crop production in Argentina (2). The disease is soybean rust, caused by Phakopsora pachyrhizi Syd. \& P. Syd.

Soybean rust is new to South America, first being found in Brazil and Paraguay in the 2001-2002 growing season and then in Argentina, in the northern province of Chaco in the 2001-2002 growing season (G. de Alvarez, Universidad del Noreste, Corrientes, Argentina, personal communication) and in the province of Misiones in the 2002-2003 growing season (3).

During 2003, soybean rust was detected by researchers at the National Institute for Agricultural Technology (INTA), in field trials at the Experimental Station of INTA Cerro Azul (province of Misiones), and in two field plots at Gobernador Virasoro (province of Corrientes) (Fig. 1). The pathogen was confirmed as $P$. pachyrhizi

\footnotetext{
Corresponding author: A. Ivancovich

E-mail: ivancovich@pergamino.inta.gov.ar
}

Accepted for publication 8 December 2004.

DOI: 10.1094/PD-89-0667

(C) 2005 The American Phytopathological Society by molecular methods (R. Frederick, personal communication). The provinces of Misiones and Corrientes are not currently considered to be important soybean production areas in Argentina. However, the occurrence of soybean rust in these provinces is of concern since the urediniospores are capable of long-distance wind dispersal, and during the soybean growing season, air currents often move from these provinces toward the main soybean area of Argentina.

\section{Symptoms}

Symptoms of soybean rust have been observed anytime during the growing season in South America, but they are more common after flowering. Symptoms begin as small, chlorotic areas on adaxial leaf surfaces that increase in size and change color from gray to reddish brown or tan. Rust symptoms and signs consist of uredinia that release urediniospores (Fig. 2). Uredinia mainly occur on the adaxial leaf surface, but they can be seen on the abaxial leaf surface as well (Fig. 3A and B). Uredinium color is important, as it indicates the type of reaction. Reddish brown lesions producing few uredinia and urediniospores on leaves are associated with the resistant reaction, while yellow lesions producing more uredinia and urediniospores are associated with the susceptible reaction.

The symptoms of soybean rust may be confused with those produced by Septoria glycines (brown spot) and Xanthomonas axonopodis pv. glycines (bacterial pustule); although with adequate magnification, rust can be easily distinguished by the presence of urediniospores.

\section{Epidemiology}

P. pachyrhizi is a biotrophic pathogen; thus it requires living plants and cannot survive on debris. It is spread primarily by windborne urediniospores that can be transported over long distances, possibly between continents. This pathogen has a wide host range, including kudzu (Pueraria

Table 1. Soybean yield in Argentina

\begin{tabular}{lr}
\hline Year & Yield $(\mathbf{t})$ \\
\hline $1975-76$ & 695,000 \\
$1985-86$ & $7,100,000$ \\
$1995-96$ & $12,450,000$ \\
$1997-98$ & $18,800,000$ \\
$1999-00$ & $20,600,000$ \\
$2000-01$ & $24,000,000$ \\
$2001-02$ & $30,000,000$ \\
$2002-03$ & $36,000,000$ \\
\hline
\end{tabular}

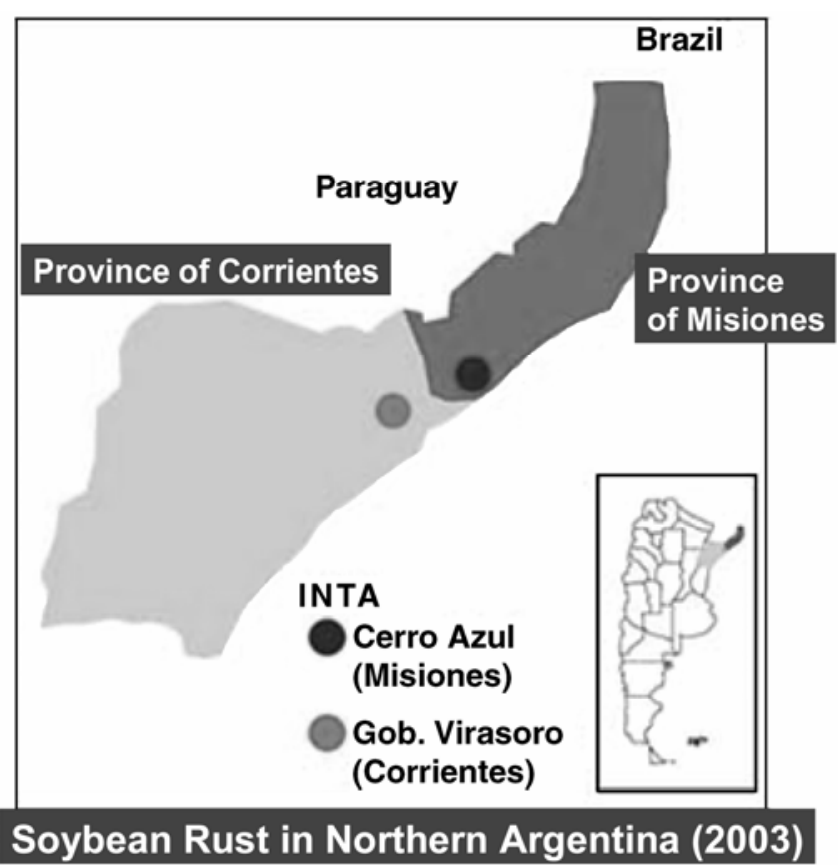

Fig. 1. Map of Northeast Argentina showing the provinces of Corrientes and Misiones where soybean rust was observed. 


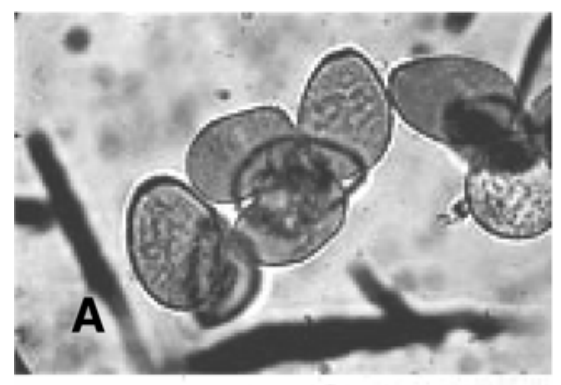

是.
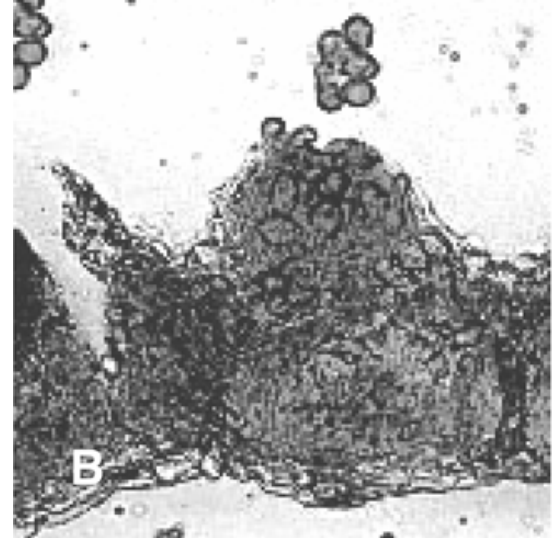

Fig. 2. A, Phakopsora pachyrhizi urediniospores and $\mathbf{B}$, rust uredium.

lobata), clover (Melilotus spp.), lupine (Lupinus hirsutus), beans (Phaseolus vulgaris), mucuna (Styzolobium niveum), cowpea (Vigna unguiculata), Cajanus cajan, Crotalaria, Dolichos, Lablab, Medicago, Pachyrhizus, Rhynchosia, and Vicia (1). Rust spores were detected on kudzu, cajanus, and mucuna in the northeastern region of the country, where these plants usually survive year-round. Spores were confirmed by molecular methods to be $P$. pachyrhizi.

Spore germination requires high humidity (75 to $80 \%$ ), with a minimum of $6 \mathrm{~h}$ of dew and temperatures between 14 and $30^{\circ} \mathrm{C}(60$ and $86^{\circ} \mathrm{F}$, respectively). After infection, uredinia are produced within 5 to 7 days, and a new generation of spores in 10 to 20 days (5).

Under ideal conditions (cool and humid weather), it is possible for the disease to increase from the initial infections to $90 \%$ of the leaf area affected in 3 weeks. These favorable conditions for rust are not uncommon in the major soybean growing areas of Argentina. Weather conditions occurring during the 2002-2003 growing season in the northern part of Buenos Aires Province, one of the main soybean growing areas of the country, would have been favorable for disease.

Losses due to soybean rust are related to the phenological stage of the plant and the severity of the symptoms. Rust causes plants to senescence early, resulting in smaller and fewer seeds.

\section{Disease Management}

The primary management options for soybean rust are the use of tolerant/ resistant cultivars and foliar fungicides.
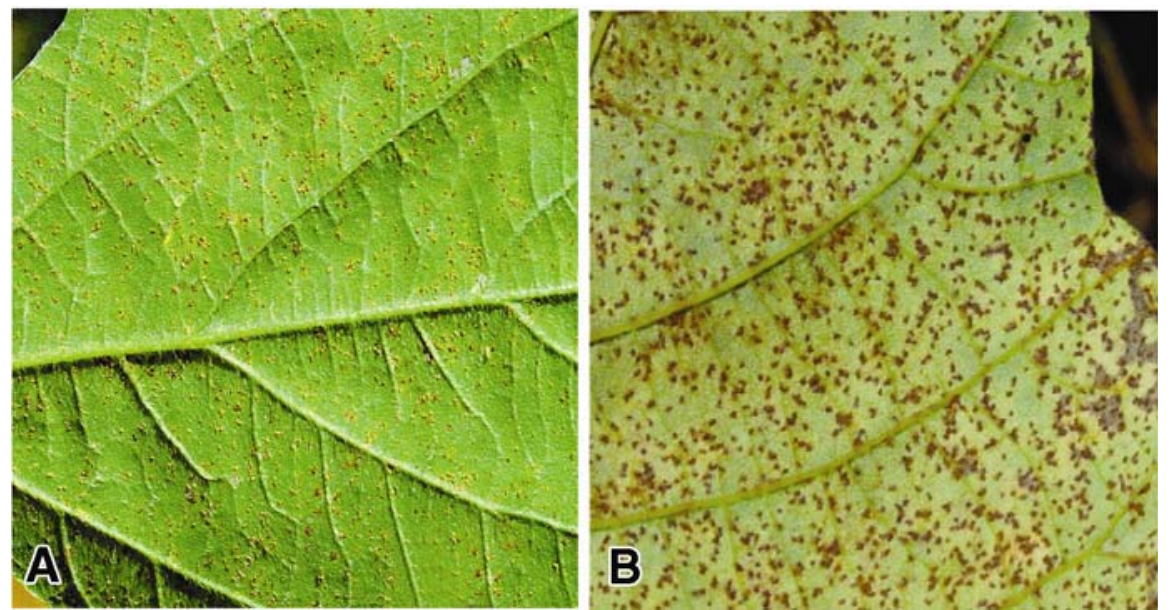

Fig. 3. A, Phakopsora pachyrhizi pustules on soybean leaf and B, symptoms on Kudzu.

There are four major genes for resistance: $R p p_{1}, R p p_{2}, R p p_{3}$, and $R p p_{4}$, identified in PI 200692, PI 230970, PI 462312 (Ankur), and PI 459025, respectively. Since available commercial varieties are susceptible, the only effective tool to reduce yield losses is the application of fungicides. Among the fungicides used to control soybean rust are: triazole fungicides (cyproconazole, difenoconazole, epoxyconazole, and tebuconazole) and strobilurin fungicides (azoxystrobin, pyraclostrobin, and trifloxystrobin) (4).

\section{National Project on Soybean Rust}

In response to the threat of rust to soybean production in Argentina, INTA's researchers initiated the National Project on Soybean Rust during the soybean growing season of 2002-2003.

The objectives of the Project are:

1. Survey soybean diseases in the northwestern and northeastern regions of Argentina with emphasis on soybean rust.

2. Review and disseminate to agricultural professionals available information on rust in South America and elsewhere in the world.

3 . Begin breeding programs for rust resistance.

4. Identify management practices that reduce disease impact.

Objective 1: Survey for the Occurrence of Soybean Rust. Grower fields and experimental plots are being examined for the occurrence of soybean rust in the northwestern and northeastern regions of Argentina. Survey sites include the National Net of Soybean Cultivar Evaluation, six additional locations in the Northeast Region, various cultivar tests and planting date studies, farmer fields, and 20 other locations around the country. Besides soybean, alternative hosts are being examined at these locations.

In the 2002-2003 season, rust was not found at any location in Chaco or Formosa provinces, even though rust had been reported in Chaco Province the year before. In Corrientes Province, rust was not detected in any experimental plots, but it was observed in two grower fields near Gobernador Virasoro. These are the first reports of rust in Corrientes Province. Rust was found in field trials at Cerro Azul, Misiones. Rust samples from all locations were identified as $P$. pachyrhizi using molecular methods at INTA Marcos Juárez by Eduardo Guillín.

Objective 2: Information on Soybean Rust. Workshops were held at INTA locations in Misiones during April 2003 and in Tucumán during May 2003. Participants in the workshops were from the provinces of Misiones, Corrientes, Entre Ríos, Chaco, Formosa, Salta, Tucumán, Córdoba, Santa $\mathrm{Fe}$, and Buenos Aires. Results of the surveys and information from the literature were presented.

Objective 3: Genetic Breeding. Possible sources of resistant germ plasm available in Argentina will be identified. Resistant cultivars will be developed using resistant germ plasm from around the world.

Objective 4: Rust Management. Efficacy of various fungicides and fungicide schedules will be evaluated along with cultural management practices such as planting date and cultivar growth habit and maturity. Combinations of these practices, such as cultivar response or fungicide effectiveness in late-planted soybean, will also be evaluated.

\section{LITERATURE CITED}

1. Bromfield, K. R. 1984. Soybean rust. Monogr. 11. American Phytopathological Society, St. Paul, MN.

2. Ivancovich, A., and Botta, G. 2002. La roya de la soja en la Argentina. EEA Pergamino. Rev. Tecnología Agropecuaria. Diciembre 2002.

3. Rossi, R. 2002. First report of Phakopsora pachyrhizi Sidow, the causal organism of Soybean Rust in the province of Misiones, Argentina. Programa Soja. Nidera Semillas S.A. Ruta $8 \mathrm{~km}$. 376. C.P. 2600. Venado Tuerto, Santa Fe, Argentina. Plant Dis. D-2002-1118-02N, 2002. Online.

4. Vello, N. A., Brogin, R. L., and Arias, C. A. A. 2002. Estrategias de melhoramento para o controle da ferrugem da soja. Anais do II Congresso Brasileiro de Soja e Mercosoja 2002. Foz do Iguazú. PR. Brasil. pp. 188-196.

5. Yang, X. B. 2002. Soybean rust: Epidemiology and management. Anais do II Congresso Brasileiro de Soja e Mercosoja 2002. Foz do Iguazú. PR. Brasil. 